\title{
Evaluation of Essential Trace and Toxic Elements in Scalp Hair Samples of Smokers and Alcohol User Hypertensive Patients
}

Hassan Imran Afridi \& Dermot Brabazon \& Tasneem Gul Kazi \& Sumsun Naher.

\begin{abstract}
The incidence of hypertension has been associated to cigarette smoking and consumption of alcohol. In the present study, trace and toxic elements were determined in scalp hair of patients diagnosed with hypertension who are smokers and habitual alcohol drinkers living in Dublin, Ireland. These results were compared with age- and sex-matched healthy, nonsmokers, nondrinking controls. The concentrations of trace and toxic elements were measured by inductively coupled plasma atomic emission spectrophotometer after microwave-assisted acid digestion. The validity and accuracy of the methodology were checked using certified reference material (NCS ZC 81002b) and by the conventional wet acid digestion method on the same certified reference material and on real samples. The recovery of all the studied elements was found to be in the range of 97.5\%-99.7\% in certified reference material. The results of this study showed that the mean values of cadmium, copper, iron, nickel and lead were significantly higher in scalp hair samples of both smoker and nonsmoker hypertensive patients than referents $(\mathrm{P}<0.001)$, whereas, the concentration of zinc was lower in the scalp hair samples of hypertensive patients of both genders. The deficiency of zinc and the high exposure of trace and toxic metals as a result of cigarette smoking and alcohol consumption may be synergistic with risk factors associated with hypertension.
\end{abstract}

Keywords Scalp hair . Cigarette smokers . Alcohol drinking . Toxic elements . Copper . Iron .Zinc . Inductively coupled plasma atomic emission spectrophotometer

\section{Introduction}

Hypertension (HT) is an increasingly important medical and public health issue. The prevalence of HT increases with advancing age (60-90 years) [1]. But nowadays, the age criteria have been changed and even people below 30 years of age have HT problems because of the lack of exercise, fast foods, smoking, coffee, and alcohol consumption [2]. Genetic effect may also be a factor [3]. Smoking, however, is an important source of exposure to toxic elements (TEs) such as cadmium $(\mathrm{Cd})$, nickel $(\mathrm{Ni})$, and lead $(\mathrm{Pb})$, which have been proposed as causative agents of cigarette smoke-induced physiological disorders [4-6]. In fact, a study showed that serious symptoms (strong urges to smoke, feeling anxious, or unsuccessful attempts at not smoking) appeared in youth within weeks or only days after the initial start of smoking [6]. 
Iron $(\mathrm{Fe})$ is an essential trace element that has been proposed to participate in free radicalproducing reactions, in particular the hydroxyl radical-producing Fenton reaction [7]. It has been shown that the pulmonary alveolar macrophages (PAM) of smokers contain increased amounts of $\mathrm{Fe}$ and ferritin, the reason for these increases is not known [8]. Although of paramount importance in normal homeostasis, especially with regard to hemoglobin, copper $(\mathrm{Cu})$ is necessary only in minute amounts in comparison with other minerals such as iron $(\mathrm{Fe})$ and zinc ( $\mathrm{Zn})$ [8]. The research in rats has been reported by Clegg et al., 1987 [9] focusing on the problems of hypocupremia. The most common manifestation of hypercupremia is hypertension. As early as 1974, the World Health Organization [10] warned that high $\mathrm{Cu}$ levels in the tissues are positively correlated with cardiovascular diseases and hypertension. Zinc is an important component of biomem-branes and an essential cofactor in a variety of enzymes [11, 12]. Zinc has antioxidant-like property, thus, it can stabilize macromolecules against radical-induced oxidation in vitro as well as limit excess radical production [13]. Zinc deficiency is associated with an increase in $\mathrm{Cd}$, as a result of the antagonistic relationships between these elements [14].

Cigarette design has evolved considerably over the last few decades with the incorporation of new tobacco processes, papers, filters, and several ingredients (flavor, humectants, and casing materials), which either alone or in combination have the potential to modify the quantity and/or the quality of the smoke yielded [15]. The tobacco plant absorbs TEs most probably from the soil, from fertilizers or from pesticides [16]. Other environmental factors that may influence the uptake of TEs by tobacco plants include the $\mathrm{pH}$ of soil, contaminated irrigated water and sewage sludge used as fertilizers. Tobacco smoking delivers 87 organic carcinogens to the lungs, in addition to TEs, [17] which may partition into the smoke phase on combustion [18]. Some of these $(\mathrm{Cd}, \mathrm{Ni}$, and $\mathrm{Pb})$ readily pass into the bloodstream and may accumulate in specific organs, such as the kidney and liver [19].

There are a few studies that have reported on the large variations of heavy metal/TEs in the compositions of commercial tobacco products, which have tried to link smoking-related diseases with TEs derived from tobacco combustion [20]. Intake of alcohol is a generally accepted behavior, but it has a significant health implications. Cross-sectional investigations have demonstrated a high prevalence of hypertension in drinkers, suggesting a possible contributory role for alcohol intake in the development of hypertension [21, 22]. Although the strong positive relationship between alcohol consumption and smoking is well established [23], a literature review found limited data on the interactions of smoking and drinking alcohol on atherosclerotic risk factors (e.g., blood pressure, serum lipids). The intake of trace and TEs may promote hypertensive and atherosclerosis disorders by increasing oxidative stress (for example, by catalyzing the production of reactive oxygen species or inhibiting their degradation) due to the deficiency of an antioxidant element ( $\mathrm{Zn}$ ) and by increasing blood pressure levels [24]. The deficiency of essential nutrients, lack of homeostatic control, or an excess intake of some TEs causes chronic physiological disorders, such as HT and cardiovascular disease [25].

Determinations of trace elements in human tissues and fluids have been used to obtain information on nutritional status for diagnosis of diseases, indication of systemic intoxication, 
and to obtain information on environmental exposure [26]. In the majority of cases, whole blood, serum, plasma, and urine were analyzed [27]. Hair can provide a more permanent record of trace and TEs associated with normal and abnormal metabolism as well as TEs assimilated from the environment [28, 29]. In addition, hair is easily collected, conveniently stored, and easily treated [30]. Therefore, the analysis of human hair has become an important method for understanding any quantitative change in certain elements inside the body $[31,32]$.

One of the most widely used analytical technique for different elements determination in biological and environmental materials is Inductively coupled plasma atomic emission spectrometry (ICP-AES) due to its advantages over other analytical methods: before all a possibility of simultaneous determination of many elements of interest, freedom from different chemical interferences and high detection power. ICP-AES also offers rapid, multielement determinations. The sensitivity of ICP-AES is lower than that of either Inductively coupled plasma mass spectrophotometer (ICP-MS) or atomic absorption graphite tube atomizer (AA-GTA), but ICP-AES can handle higher levels of total dissolved solids (TDS) than ICP-MS and is much faster than AA-GTA [33, 34]. Since ICP-AES is able to analyze samples with higher TDS, more concentrated solutions can be prepared allowing trace elements to be measured. The main advantage of microwave-assisted samples pretreatment is its requirement of small amount of mineral acids and a reduction in the production of nitrous vapors. Microwave systems keep blank levels low because only small volumes of reagents are required and allow more samples to be processed per hour than conventional digestion systems [35].

The aim and objective of our present study was to assess the concentrations of $\mathrm{Cd}, \mathrm{Cu}, \mathrm{Fe}$, $\mathrm{Ni}, \mathrm{Pb}$, and $\mathrm{Zn}$ in the scalp hair samples of smoker and alcohol user hypertensive patients. For a comparative study, 54 nonhypertensive individuals (smoker and alcohol user) of the same age group (range, 30-50 years), socioeconomic status, localities and dietary habits were selected as referents. The understudy elements were analyzed by inductively coupled plasma atomic emission spectrophotometer, after microwave-assisted acid digestion.

\section{Materials and Methods}

\section{Apparatus}

A Varian Liberty 220 (Mulgrave, Victoria, Australia) inductively coupled plasma atomic emission spectrometer with the axially viewed plasma was used for the analysis. The Liberty Series II ICP features a $40 \mathrm{MHz}$ free-running RF generator, a $0.75 \mathrm{~m}$ Czemy-Turner monochromator with 1,800 grooves/mm holographic grating used in up to four orders. The resolution of the spectrometer is typically $0.018 \mathrm{~nm}$ in $1 \mathrm{st}$ order, $0.009 \mathrm{~nm}$ in 2nd order, $0.007 \mathrm{~nm}$ in 3rd order, and $0.006 \mathrm{~nm}$ in 4th order. The instrument was controlled with a digital equipment corporation Venturis computer with an Intel Pentium processor and Varian Plasma 96 software running under Microsoft Windows 95 operating system. The instrumental conditions are shown in Tables 1 and 2. A Hinari Life style (Elstree, Hertfordshire, England) 
domestic microwave oven (maximum heating power of $800 \mathrm{~W}$ ) was used for digestion of the scalp hair samples. Acid-washed polytetrafluoroethylene (PTFE) vessels and flasks were used for preparing and storing solutions.

\begin{tabular}{|c|c|c|c|c|c|c|}
\hline Parameters & $\mathrm{Cd}$ & $\mathrm{Cu}$ & $\mathrm{Fe}$ & $\mathrm{Ni}$ & $\mathrm{Pb}$ & $\mathrm{Zn}$ \\
\hline Wavelength (nm) & 226.502 & 327.396 & 238.204 & 231.604 & 220.553 & 213.8 \\
\hline Height (mm) & 3 & 5 & 5 & 5 & 3 & 5 \\
\hline Windows (nm) (above the coil) & 0.027 & 0.027 & 0.027 & 0.027 & 0.027 & 0.027 \\
\hline Scan (nm) & 0.040 & 0.040 & 0.040 & 0.040 & 0.040 & 0.040 \\
\hline Integration (s) & 3 & 3 & 3 & 3 & 3 & 3 \\
\hline Replicates & 3 & 3 & 3 & 3 & 3 & 3 \\
\hline Sample uptake (s) & 30 & 30 & 30 & 30 & 30 & 30 \\
\hline PMT (V) & 650 & 650 & 650 & 650 & 650 & 650 \\
\hline Power (kW) & 1.10 & 1.10 & 1.10 & 1.10 & 1.10 & 1.10 \\
\hline Plasma flow (L/min) & 15.0 & 15.0 & 15.0 & 15.0 & 15.0 & 15.0 \\
\hline Auxiliary flow (L/min) & 1.50 & 1.50 & 1.50 & 1.50 & 1.50 & 1.50 \\
\hline Pump Speed (rpm) & 15 & 15 & 15 & 15 & 15 & 15 \\
\hline Background mode & Dynamic & Dynamic & Dynamic & Dynamic & Dynamic & Dynamic \\
\hline Max curve order & 1 & 1 & 1 & 1 & 1 & 1 \\
\hline C.C. limit & 0.995 & 0.995 & 0.995 & 0.995 & 0.995 & 0.995 \\
\hline \multirow[t]{9}{*}{$\begin{array}{l}\text { Table } 2 \text { Liberty } 220 \text { common } \\
\text { parameters }\end{array}$} & \multicolumn{4}{|c|}{ Nebulizer type } & \multicolumn{2}{|l|}{$\mathrm{V}$ groove } \\
\hline & \multicolumn{3}{|c|}{ Nebulizer pressure } & & \multicolumn{2}{|l|}{$150 \mathrm{kPa}$} \\
\hline & \multicolumn{3}{|c|}{ Stabilization time } & & \multicolumn{2}{|l|}{$10 \mathrm{~s}$} \\
\hline & \multicolumn{3}{|c|}{ Sample delay time } & & \multicolumn{2}{|l|}{$30 \mathrm{~s}$} \\
\hline & \multicolumn{3}{|c|}{ Rinse time } & & \multicolumn{2}{|l|}{$10 \mathrm{~s}$} \\
\hline & \multirow{2}{*}{\multicolumn{2}{|c|}{ Pump tube }} & & & \multirow{2}{*}{\multicolumn{2}{|c|}{$\begin{array}{l}\text { Orange-orange (inlet) } \\
\text { Blue-blue (outlet) }\end{array}$}} \\
\hline & & & & & & \\
\hline & \multicolumn{2}{|c|}{ Snout purge } & & & \multicolumn{2}{|l|}{ Off } \\
\hline & \multicolumn{2}{|c|}{ Fast pump } & & & \multicolumn{2}{|l|}{ On } \\
\hline
\end{tabular}

\section{Reagents and Glass Wares}

Ultrapure water obtained from ELGA Lab Water system (Bucks, UK) was used throughout the work. Concentrated nitric acid (65\%) and hydrogen peroxide $(30 \%)$ were obtained from Merck (Darmstadt, Germany), and checked for possible trace metal contamination. Working standard solutions of $\mathrm{Cd}, \mathrm{Cu}, \mathrm{Fe}, \mathrm{Ni}, \mathrm{Pb}$, and $\mathrm{Zn}$ were prepared immediately prior to their use, by stepwise dilution of certified standard solutions (1,000 ppm) Fluka Kamica (Buchs, Switzerland), with $0.5 \mathrm{M} \mathrm{HNO3}$. All solutions were stored in polyethylene bottles at $4{ }^{\circ} \mathrm{C}$. For the accuracy of methodology, the certified reference material, human hair NCSZN 81002b (Beijing, China), was used (Table 3). All glassware and plastic materials used were previously soaked for $24 \mathrm{~h}$ in $5 \mathrm{M}$ nitric acid, washed with distilled and finally rinsed with ultrapure water, dried, and stored in a class 100 laminar flow hoods. 


$\begin{aligned} & \text { Table 3 } \\
& \text { and microwave digestion method (MWD) }(n=10)\end{aligned}$
\begin{tabular}{|lrrrrc} 
Elements & $\begin{array}{l}\text { Conventional digestion } \\
\text { method CDM }\end{array}$ & $\begin{array}{l}\text { Microwave digestion } \\
\text { method MWD }\end{array}$ & $T$ value $^{\mathrm{a}}$ & \% recovery & \\
\hline $\mathrm{Cd}$ & $0.0716 \pm 0.003(4.19)$ & $0.0714 \pm 0.006(8.40)$ & 0.305 & 99.7 & $0.072 \pm 0.010$ \\
$\mathrm{Cu}$ & $33.5 \pm 1.92(5.73)$ & $33.0 \pm 1.58(4.79)$ & 0.193 & 98.5 & $33.6 \pm 2.3$ \\
$\mathrm{Fe}$ & $158 \pm 6.73(4.26)$ & $154 \pm 8.72(5.66)$ & 0.182 & 97.5 & $160 \pm 16$ \\
$\mathrm{Ni}$ & $5.71 \pm 0.51(8.93)$ & $5.67 \pm 0.43(7.58)$ & 0.339 & 99.4 & $5.77^{*}$ \\
$\mathrm{~Pb}$ & $3.80 \pm 0.37(9.74)$ & $3.72 \pm 0.35(9.41)$ & 0.081 & 98.05 & $3.83 \pm 0.18$ \\
$\mathrm{Zn}$ & $191 \pm 7.28(3.81)$ & $187 \pm 9.53(5.09)$ & 0.648 & 97.9 & $191 \pm 16$ \\
\hline
\end{tabular}

\section{Sample Collection and Pretreatment}

Before the start of this study, all referents and hypertension patients of both genders, age range 30-50 years, were informed through a consent form by the administration about the aim of study, and all agreed to participate and signed the form. A questionnaire was also administered to them to collect details regarding physical data, ethnic origin, health, duration of smoking and drinking the alcohol, frequency of smoking and drinking alcohol, dietary habits, age, and consent. The patients were grouped according to their habits, not smoking or alcohol users patients (PNACS), cigarette smoking patients (PCS), alcohol users patients (PAD), and alcohol consumption with cigarette smoking patients (PACS). While control group are also divided into four groups: first group, not smoking or alcohol users referents (RNACS), second cigarette smoker referents (RCS), third alcohol users referents (RAD) while last group had alcohol consumption with cigarette smoking (RACS) as shown in Table 4.

\begin{tabular}{|c|c|c|c|c|}
\hline \multirow[t]{2}{*}{ Parameters } & \multicolumn{2}{|l|}{ Referents } & \multicolumn{2}{|c|}{ Hypertensive patients } \\
\hline & Male & Female & Male & Female \\
\hline \multicolumn{5}{|l|}{ Occupation } \\
\hline Labor & 32 & 25 & 35 & 28 \\
\hline Office workers & 29 & 12 & 23 & 15 \\
\hline Not working & 09 & 21 & 13 & 13 \\
\hline \multicolumn{5}{|l|}{ Habits } \\
\hline Smoking tobacco & $11(15.7 \%)$ & $10(17.2 \%)$ & $20(28.2 \%)$ & $15(26.8 \%)$ \\
\hline Alcohol drinkers & $19(27.1 \%)$ & $14(24.1 \%)$ & $16(22.5 \%)$ & $16(28.6 \%)$ \\
\hline Smoking tobacco + alcohol drinkers & $15(21.5 \%)$ & $11(19.0 \%)$ & $13(18.3 \%)$ & $12(21.4 \%)$ \\
\hline Nonsmoking tobacco and alcohol drinkers & $25(35.7 \%)$ & $23(39.7 \%)$ & $22(31 \%)$ & $13(23.2 \%)$ \\
\hline
\end{tabular}

Physical examinations were carried out to measure participant's weight, height and blood pressure. For all patients and referents, anthropometric parameters including weight, height and waist circumference were measured using the standard protocols (Table 5). 


\begin{tabular}{|c|c|c|c|c|c|c|c|c|}
\hline \multirow[t]{2}{*}{ Parameters } & \multicolumn{4}{|l|}{ Referents } & \multicolumn{4}{|l|}{ Patients } \\
\hline & RNACS & RACS & RCS & RAD & PNACS & PACS & PCS & PAD \\
\hline \multicolumn{9}{|l|}{ Male } \\
\hline Height $(\mathrm{cm})$ & $180.3 \pm 2.5$ & $182.9 \pm 1.4$ & $181.6 \pm 0.9$ & $180.8 \pm 1.6$ & $179.6 \pm 1.32$ & $184.4 \pm 2.32$ & $179.8 \pm 0.83$ & $181.2 \pm 1.7$ \\
\hline Weight (kg) & $79.4 \pm 1.3$ & $83.7 \pm 2.42$ & $82.1 \pm 1.13$ & $84.9 \pm 2.26$ & $80.3 \pm 2.54$ & $83.5 \pm 1.35$ & $82.6 \pm 2.68$ & $84.3 \pm 1.12$ \\
\hline Waist circumference $(\mathrm{cm})$ & $76.4 \pm 1.43$ & $80.3 \pm 1.52$ & $79.5 \pm 1.36$ & $83.1 \pm 1.07$ & $86.2 \pm 1.43$ & $82.5 \pm 1.28$ & $87.6 \pm 1.22$ & $88.3 \pm 1.38$ \\
\hline BMI $\left(\mathrm{kg} / \mathrm{m}^{2}\right)$ & $24.4 \pm 2.0$ & $25.0 \pm 1.5$ & $24.9 \pm 0.85$ & $25.9 \pm 2.2$ & $24.9 \pm 1.6$ & $24.6 \pm 1.3$ & $25.5 \pm 1.34$ & $25.7 \pm 1.51$ \\
\hline Systolic BP (mmHg) & $119.3 \pm 3.1$ & $126.2 \pm 1.2$ & $122.7 \pm 2.4$ & $124.5 \pm 1.5$ & $152.2 \pm 2.8$ & $156.7 \pm 2.4$ & $160.5 \pm 1.06$ & $163.5 \pm 1.52$ \\
\hline Diastolic BP (mmHg) & $79.9 \pm 2.7$ & $89.2 \pm 1.48$ & $83.2 \pm 0.92$ & $85.3 \pm 1.74$ & $96.5 \pm 1.42$ & $98.5 \pm 2.35$ & $99.2 \pm 0.62$ & $101.3 \pm 1.25$ \\
\hline \multicolumn{9}{|l|}{ Female } \\
\hline Height $(\mathrm{cm})$ & $164.2 \pm 1.28$ & $163.4 \pm 0.8$ & $165.2 \pm 1.0$ & $164 \pm 1.02$ & $165.1 \pm 0.95$ & $164.2 \pm 0.76$ & $164.3 \pm 0.82$ & $164.5 \pm 0.87$ \\
\hline Weight (kg) & $60.5 \pm 1.26$ & $64.5 \pm 1.42$ & $62.3 \pm 0.72$ & $63.1 \pm 1.31$ & $62.2 \pm 1.73$ & $67.8 \pm 0.78$ & $64.7 \pm 0.55$ & $65.9 \pm 2.16$ \\
\hline Waist circumference $(\mathrm{cm})$ & $63.3 \pm 1.38$ & $65.2 \pm 1.21$ & $64.6 \pm 1.41$ & $65.8 \pm 1.54$ & $64.4 \pm 1.04$ & $65.9 \pm 1.21$ & $65.2 \pm 0.49$ & $65.6 \pm 0.82$ \\
\hline BMI $\left(\mathrm{kg} / \mathrm{m}^{2}\right)$ & $22.4 \pm 1.57$ & $24.2 \pm 1.93$ & $22.8 \pm 1.65$ & $23.5 \pm 2.34$ & $22.8 \pm 1.57$ & $25.2 \pm 0.85$ & $23.9 \pm 1.74$ & $24.3 \pm 2.16$ \\
\hline Systolic BP (mmHg) & $119.1 \pm 1.2$ & $123.5 \pm 1.3$ & $120.7 \pm 0.5$ & $122.1 \pm 1.3$ & $150.4 \pm 1.92$ & $153.2 \pm 1.42$ & $158.5 \pm 1.21$ & $160.3 \pm 1.62$ \\
\hline Diastolic BP (mmHg) & $80.1 \pm 0.93$ & $86.4 \pm 1.35$ & $83.5 \pm 0.61$ & $84.9 \pm 1.56$ & $95.2 \pm 1.25$ & $97.2 \pm 1.24$ & $96.5 \pm 0.47$ & $99.2 \pm 1.18$ \\
\hline
\end{tabular}

BMI body mass index

There were no statistically significant differences between both groups of patients and referents with regard to height and weight. The 62\% hypertensive patient used antihypertensive drugs. This research project was evaluated and approved by the Higher Education Commission, Pakistan.

The hypertensive patients, who had blood pressure exceeding 130/95 $\mathrm{mmHg}$ (systolic/ diastolic), were admitted for their uncontrolled HT and had earlier histories of high blood pressure. The criteria of healthy subjects included no history of symptoms of hypertension and any coronary disease documented in their medical notes, and no family history of heart disease was defined by a first-degree relative with a myocardial infarction (MI), or cardiac death before the age of 55 years. All control subjects underwent a routine medical examination including MI test. All patients and controls/referents were requested to complete an interviewer-administered questionnaire, concerning their demographic characteristics, age, health history, lifestyle habits, and diet. They gave written consent to participate in the study.

\section{Collection of Scalp Hair Samples}

The hair samples $(-1.0 \mathrm{~g}$ each) were taken from the nape of the neck. Hair samples were put into separate plastic envelopes for each participant, on which the identification (ID) number of the participant was indicated. The plastic envelope of each subject was tightly sealed and attached to a questionnaire. Before analysis, each individual hair sample was cut into approximately $0.5-\mathrm{cm}$-long pieces and mixed to allow a representative subsampling of the hair specimen. After cutting, each sample was washed with diluted Triton X-100, then samples were rinsed with distilled water and then with deionized water. The samples were then rinsed three times with acetone [35]. The samples were then dried in an oven at $75 \pm 5^{\circ} \mathrm{C}$ for $2 \mathrm{~h}$. Dried samples were stored separately in polyethylene bags. 


\section{Microwave-Assisted Acid Digestion}

A microwave-assisted digestion (MWD) procedure was carried out, in order to achieve a shorter digestion time. Duplicate samples of scalp hair (200 mg) of each hypertensive patients and control individuals were directly placed into Teflon PFA flasks. Two milliliters of a freshly prepared mixture of concentrated HNO3-H202 (2:1 v/v) were added to each flask and kept for 10 min at room temperature then placed in a covered PTFE container. This was then heated following a one-stage digestion program at $80 \%$ of total power $(800 \mathrm{~W})$. Complete digestion of scalp hair samples required 5-8 min. After the digestion, the flasks were left to cool and the resulting solution was evaporated to semidried mass to remove excess acid. About $5 \mathrm{~mL}$ of $0.1 \mathrm{M}$ nitric acid was added to the residue and filtered through a Whatman no. 42 filter paper and diluted with deionized water up to $10.0 \mathrm{~mL}$ in volumetric flasks. Blank extractions were carried through the complete procedure. Blanks and standard solutions were prepared in a similar acid matrix. The validity and efficiency of the MWD method was checked with certified values of human hair NCSZC 81002b and with those obtained from conventional wet acid digestion method [31].

\section{Analytical Figures of Merit}

Statistical analyses were performed using computer program Excel XL State (Microsoft Corp., Redmond, WA) and Minitab 13.2 (Minitab Inc., State College, PA). The Student's t test was used to assess the significance of the differences in concentrations of elements among study subjects.

Calibration was performed with a series of $\mathrm{Cd}, \mathrm{Cu}, \mathrm{Fe}, \mathrm{Ni}, \mathrm{Pb}$, and $\mathrm{Zn}$ standards. Sensitivity (m) was the slope value obtained by least-square regression analysis of calibration curves based on absorbance signals. The equation $(n=5)$ for the calibration curves was as follows:

$$
\begin{aligned}
& Y=\left(1.28 \times 10^{-3} \pm 8.60 \times 10^{-5}\right)(\mathrm{Cd})+\left(1.30 \times 10^{-3} \pm 1.23 \times 10^{-4}\right), r=0.999 \\
& Y=\left(4.38 \times 10^{-2} \pm 7.11 \times 10^{-3}\right)(\mathrm{Cu})+\left(4.39 \times 10^{-2} \pm 7.25 \times 10^{-3}\right), r=0.999 \\
& Y=\left(1.38 \times 10^{-3} \pm 9.41 \times 10^{-4}\right)(\mathrm{Fe})+\left(1.40 \times 10^{-3} \pm 8.07 \times 10^{-4}\right), r=0.999 \\
& Y=\left(1.66 \times 10^{-2} \pm 2.24 \times 10^{-3}\right)(\mathrm{Ni})+\left(1.73 \times 10^{-2} \pm 2.92 \times 10^{-3}\right), r=0.999 \\
& Y=\left(1.875 \times 10^{-2} \pm 7.40 \times 10^{-4}\right)(\mathrm{Pb})+\left(1.91 \times 10^{-2} \pm 5.83 \times 10^{-3}\right), r=0.999 \\
& Y=\left(7.83 \times 10^{-2} \pm 1.18 \times 10^{-2}\right)(\mathrm{Zn})+\left(8.51 \times 10^{-2} \pm 1.03 \times 10^{-2}\right), r=0.999
\end{aligned}
$$

where $\mathrm{Y}$ is the integrated absorbance, $\mathrm{r}$ is the regression and the concentration range of As, $\mathrm{Cd}$, and $\mathrm{Pb}$ for calibration curve reached from the detection limits up to $100 \mu \mathrm{g} / \mathrm{L}$. The limit of detection, equal to $0.0003 \mathrm{ng} / \mathrm{mg}, 0.01 \mathrm{ng} / \mathrm{mg}, 0.01 \mathrm{ng} / \mathrm{mg}, 0.01 \mathrm{ng} / \mathrm{mg}, 0.0003 \mathrm{ng} / \mathrm{mg}$ and $0.01 \mathrm{ng} / \mathrm{mg}$ for $\mathrm{Cd}, \mathrm{Cu}, \mathrm{Fe}, \mathrm{Ni}, \mathrm{Pb}$, and $\mathrm{Zn}$, respectively, was defined as $3 \mathrm{~s} / \mathrm{m}$, "s" being the standard deviation corresponding to ten blank injections and 'In' the slope of the calibration graph. The quantification limits, defined as $10 \mathrm{~s} / \mathrm{m}$ were calculated as: 0.0009, 0.03, 0.03, $0.05,0.001$, and $0.04 \mathrm{ng} / \mathrm{mg}$ for $\mathrm{Cd}, \mathrm{Cu}, \mathrm{Fe}, \mathrm{Ni}, \mathrm{Pb}$, and $\mathrm{Zn}$, respectively. 


\section{Results}

In the study population, $\sim 48 \%$ of HT patients and $\sim 37 \%$ of referents were smokers, whilst $50 \%$ HT patients and $49 \%$ referents were alcohol drinkers. Blood pressure was measured in the population under study in the sitting position after a 5-min rest. A patient was diagnosed as having HT if systolic blood pressure was $>150 \mathrm{mmHg}$, diastolic pressure was $>90 \mathrm{mmHg}$ and if the patient was receiving drug treatment for HT. The other physical parameters of both groups of patients and referents were obtained by a standard method as shown in Table 5. The weight, body mass index, and blood pressure (systolic and diastolic blood pressure) levels of HT patients were significantly higher than those in healthy referents $(\mathrm{P}<0.05)$. The smoker and alcohol drinker referents weighed more than nonsmoker referents $(\mathrm{P}=0.042)$.

The elemental contents in the scalp hair samples varied widely among individuals; thus, a significantly large number of samples were required for statistical interpretation of the data to achieve a meaningful correlation between physiological disorders and concentrations of trace and TEs. The mean concentrations with standard deviations for each element in biological samples, as shown in Table 6, indicate that the concentrations of the essential trace element $(\mathrm{Cu}, \mathrm{Fe}$, and $\mathrm{Zn})$ and TEs $(\mathrm{Cd}, \mathrm{Ni}$, and $\mathrm{Pb})$ were altered in the scalp hair samples of smoker and alcohol drinker-hypertensive patients, whereas in the case of RCS, there is no significant difference for $\mathrm{Zn}$, although the levels of other trace elements were higher in their scalp hair samples.

The concentrations of $\mathrm{Zn}$ in the scalp hair samples of male RNACS and RCS were significantly higher at 95\% confidence interval (CI, 263 and 275) and (221 and 232) $\mu \mathrm{g} / \mathrm{g}$, respectively, compared with those in PNACS and PCS, (CI, 203 and 232) and (CI, 157 and 172) $\mu \mathrm{g} / \mathrm{g}$, respectively, with $\mathrm{P}<0.001$. The Zn levels in the scalp hair samples of RACS and RAD, (CI, 175 and 190) and (CI, 196 and 210) $\mu \mathrm{g} / \mathrm{g}$, respectively, were found to be higher than those in PACS and PAD, (CI, 97.4 and 120) and (CI, 122 and 129) $\mu \mathrm{g} / \mathrm{g}$, respectively, $(\mathrm{P}=0.001-0.002)$.

\begin{tabular}{|c|c|c|c|c|c|c|c|c|}
\hline \multirow[t]{2}{*}{ Elements } & \multicolumn{4}{|l|}{ Referents } & \multicolumn{4}{|l|}{ Patients } \\
\hline & RNACS & RACS & RCS & RAD & PNACS & PACS & PCS & PAD \\
\hline \multicolumn{9}{|l|}{ Male } \\
\hline Cadmium & $0.64 \pm 0.12$ & $2.45 \pm 0.20$ & $1.45 \pm 0.16$ & $1.60 \pm 0.27$ & $2.1 \pm 0.11$ & $3.86 \pm 0.54$ & $2.58 \pm 0.21$ & $2.71 \pm 0.38$ \\
\hline Copper & $11.7 \pm 1.46$ & $18.3 \pm 3.5$ & $14.8 \pm 2.15$ & $15.4 \pm 2.74$ & $18.5 \pm 1.40$ & $33.5 \pm 1.66$ & $28.0 \pm 3.46$ & $30.9 \pm 1.59$ \\
\hline Iron & $18.4 \pm 3.02$ & $25.6 \pm 1.86$ & $19.2 \pm 2.92$ & $25.3 \pm 0.85$ & $23.5 \pm 1.28$ & $38.2 \pm 0.83$ & $28.0 \pm 5.06$ & $32.1 \pm 3.26$ \\
\hline Nickel & $1.78 \pm 0.29$ & $5.02 \pm 0.54$ & $3.32 \pm 0.34$ & $4.6 \pm 1.04$ & $3.89 \pm 0.38$ & $8.36 \pm 1.39$ & $6.2 \pm 0.59$ & $6.4 \pm 0.76$ \\
\hline Lead & $3.29 \pm 0.41$ & $5.79 \pm 0.26$ & $4.73 \pm 0.31$ & $5.15 \pm 0.27$ & $5.11 \pm 0.30$ & $9.01 \pm 1.25$ & $7.37 \pm 0.30$ & $8.22 \pm 0.70$ \\
\hline Zine & $269 \pm 11.3$ & $185 \pm 9.04$ & $226 \pm 10.6$ & $203 \pm 13.9$ & $218 \pm 31.2$ & $109 \pm 21.4$ & $164 \pm 16.9$ & $126 \pm 5.82$ \\
\hline \multicolumn{9}{|l|}{ Female } \\
\hline Cadmium & $0.51 \pm 0.10$ & $2.33 \pm 0.14$ & $1.28 \pm 0.11$ & $1.44 \pm 0.16$ & $1.94 \pm 0.12$ & $3.54 \pm 0.26$ & $2.37 \pm 0.17$ & $2.71 \pm 0.14$ \\
\hline Copper & $11.1 \pm 1.18$ & $17.8 \pm 2.19$ & $16.1 \pm 2.73$ & $15.5 \pm 1.65$ & $18.0 \pm 1.41$ & $32.2 \pm 1.23$ & $26.9 \pm 1.57$ & $29.3 \pm 1.12$ \\
\hline Iron & $19.4 \pm 1.54$ & $25.1 \pm 0.93$ & $22.6 \pm 1.94$ & $24.1 \pm 1.21$ & $25.4 \pm 1.36$ & $35.6 \pm 2.15$ & $30.9 \pm 2.51$ & $32.4 \pm 1.70$ \\
\hline Nickel & $1.62 \pm 0.41$ & $4.81 \pm 0.63$ & $3.50 \pm 0.47$ & $4.10 \pm 0.35$ & $3.40 \pm 0.43$ & $8.74 \pm 1.05$ & $5.62 \pm 0.43$ & $6.33 \pm 1.00$ \\
\hline Lead & $3.18 \pm 0.32$ & $5.43 \pm 0.24$ & $4.21 \pm 0.15$ & $4.93 \pm 0.26$ & $5.16 \pm 0.22$ & $8.82 \pm 1.42$ & $7.17 \pm 0.35$ & $8.21 \pm 0.41$ \\
\hline Zinc & $256 \pm 9.88$ & $159 \pm 9.96$ & $213 \pm 8.69$ & $185 \pm 11.1$ & $211 \pm 22.0$ & $98.8 \pm 5.66$ & $154 \pm 10.7$ & $116 \pm 4.18$ \\
\hline
\end{tabular}


The same trend was observed in female case (Table 6). It was observed that the level of $\mathrm{Zn}$ did not vary significantly in the scalp samples of referent smokers and alcohol users, indicating that the alteration of $\mathrm{Zn}$ in scalp hair samples of smokers and alcohol drinkerhypertensive patients was mainly because of the disease state of the patients. The levels of $\mathrm{Cu}$ and $\mathrm{Fe}$ in scalp hair samples were statistically significantly higher $(\mathrm{P}<0.01)$ in smoker and alcohol users hypertensive patients of both genders, although RCS and RAD also had high levels of these trace elements in their scalp hair samples (Table 6). An elevated level of $\mathrm{Cd}$ content was observed in the scalp hair of female RNACS and RCS. The ranges of Cd in the scalp hair samples of RACS and RAD were (CI, 2.20-2.41) and (CI, 1.37-1.52) $\mu \mathrm{g} / \mathrm{g}$, respectively, whereas those in PACS and PAD were (CI, 3.40-3.59) pg/g and (CI, 2.62-2.80) i.tg/g, respectively, $(\mathrm{P}<0.002)$.

The same trend was observed in male cases (Table 6). The Pb concentration in the scalp hair samples of male RNACS was found at $95 \% \mathrm{CI}$, (3.07 and 3.50) $\mu \mathrm{g} / \mathrm{g}$, whereas in the PNACS, the $\mathrm{Pb}$ level was in the range of (CI, 4.94-5.26) $\mathrm{gg} / \mathrm{g}$ (Table 5). Similarly, a higher level of $\mathrm{Pb}$ was observed in PACS (CI, 8.83-9.15) [ig/g, PCS (CI, 7.15-7.52) 4g/g and PAD (CI, 7.768.50) $\mathrm{Rg} / \mathrm{g}$ than in RNACS $(\mathrm{P}<0.001)$. The same trend was observed in females (Table 6). The levels of $\mathrm{Ni}$ in the scalp hair samples of female RNACS and RCS were found to be lower, (CI, 1.41-1.83) and (CI, 3.27-3.74) $\mu \mathrm{g} / \mathrm{g}$, respectively, compared with those in PNACS and PCS, (CI, 3.21-3.62) and (CI, 5.43-5.84) pg/g, respectively. The ranges of $\mathrm{Ni}$ concentration in the scalp hair samples of RACS and RAD were (CI, 4.52-5.13) and (CI, 3.92-4.28) $\mu \mathrm{g} / \mathrm{g}$, respectively, compared with those of PACS and PAD, (CI, 8.20-9.11) and (CI, 5.82-6.85) $\mu \mathrm{g} / \mathrm{g}$, respectively.

The same trend was observed in males (Table 6) $(\mathrm{P}>0.002)$. The unpaired student t test at different degrees of freedom between hypertensive patients and referents of both genders were calculated at different probabilities. Our calculated tvalue exceeds that of tcritical value at $95 \%$ confidence intervals, which indicated the significant differences between mean values of understudy elements in referents and hypertensive patients $(\mathrm{p}<0.001)$. The inter-elemental correlation ( $r$ ) of $\mathrm{Zn}$ versus trace and TEs in hypertensive patients and referents indicates that the values of $\mathrm{Zn}$ in scalp hair of PACS and PAD have low correlation ( $r=0.05-0.17$; Table 7). $\mathrm{The} \mathrm{Zn} / \mathrm{Cd}, \mathrm{Zn} / \mathrm{Cu}, \mathrm{Zn} / \mathrm{Fe}, \mathrm{Zn} / \mathrm{Ni}$, and $\mathrm{Zn} / \mathrm{Pb}$ ratio were varied in the scalp hair samples of referents as compared to the hypertensive patients of both genders in age group (30-50) years (Table 8).

\section{Discussion}

This study provides data on the essential trace element $(\mathrm{Zn}, \mathrm{Cu}$, and $\mathrm{Fe}$ ) and TEs $(\mathrm{Cd}, \mathrm{Ni}$, and $\mathrm{Pb}$ ) in scalp hair samples obtained from smoker and alcohol user hypertensive and nonhypertensive referents of both genders of age group (30-50) years. There are many causes of high blood pressure, such as smoking, obesity, poor diet, lack of cold water fish, fresh fruits, vegetables, exercise, poor sleep, genetics, stress, and insomnia. Drinking too much alcohol can raise the levels of some fats in the blood (triglycerides). 


\begin{tabular}{|c|c|c|c|c|c|c|c|c|}
\hline \multirow[t]{2}{*}{ Elements } & \multicolumn{4}{|l|}{ Referents } & \multicolumn{4}{|l|}{ Patients } \\
\hline & RNACS & RACS & RCS & RAD & PNACS & PACS & PCS & PAD \\
\hline \multicolumn{9}{|l|}{ Male } \\
\hline $\begin{array}{l}\text { Cadmium } \\
(R)\end{array}$ & $0.009 x-1.87(0.90)$ & $0.007 x+1.08(0.33)$ & $-0.008 x+3.28(0.51)$ & $-0.01 x+3.59(0.50)$ & $-0.0009 x+2.28(0.25)$ & $0.0017 x+3.68(0.07)$ & $0.0025 x+2.17(0.20)$ & $0.0116 x+1.25(0.18)$ \\
\hline Copper $(R)$ & $0.109 x-17.6(0.84)$ & $0.139 x-7.55(0.36)$ & $0.116 x-11.55(0.57)$ & $-0.077 x+30.9(0.39)$ & $-0.015 x+21.8(0.34)$ & $0.009 x+32.2(0.13)$ & $-0.054 x+36.9(0.26)$ & $0.06 x+23.4(0.22)$ \\
\hline Iron $(R)$ & $0.217 x-39.9(0.81)$ & $-0.0698 x+38.5(0.34)$ & $0.148 x-14.3(0.54)$ & $0.026 x+19.96(0.42)$ & $-0.0148 x+26.7(0.36)$ & $0.0039 x+37.7(0.10)$ & $0.0918 x+12.9(0.31)$ & $0.073 x+22.9(0.13)$ \\
\hline Nickel $(R)$ & $0.023 x-4.32(0.88)$ & $0.0164 x+1.97(0.28)$ & $0.0178 x-0.71(0.56)$ & $0.028 x-1.17(0.38)$ & $-0.0031 x+4.56(0.25)$ & $-0.004 x+8.79(0.06)$ & $0.0086 x+4.80(0.24)$ & $0.02 x+3.81(0.15)$ \\
\hline Lead $(R)$ & $0.029 x-4.47(0.79)$ & $0.0096 x+3.99(0.34)$ & $0.014 x+1.51(0.49)$ & $0.0069 x+3.74(0.35)$ & $0.0022 x+4.63(0.22)$ & $-0.009 x+10.0(0.16)$ & $0.0017 x+7.09(0.10)$ & $0.02 x+5.63(0.17)$ \\
\hline \multicolumn{9}{|l|}{ Female } \\
\hline $\begin{array}{l}\text { Cadmium } \\
(R)\end{array}$ & $0.0089 x-1.78(0.85)$ & $0.005 x+1.53(0.38)$ & $-0.003 x+1.71(0.45)$ & $0.0065 x+0.23(0.44)$ & $-0.0013 x+2.20(0.24)$ & $0.0026 x+3.29(0.06)$ & $0.0018 x+1.96(0.11)$ & $0.0028 x+2.39(0.08)$ \\
\hline Copper $(R)$ & $0.108 x-16.5(0.90)$ & $0.0504 x+9.73(0.23)$ & $-0.057 x+25.6(0.35)$ & $0.0468 x+6.88(0.31)$ & $-0.0117 x+20.4(0.18)$ & $-0.0145 x+33.7(0.07)$ & $-0.021 x+30.2(0.14)$ & $-0.02 x+32.0(0.09)$ \\
\hline Iron $(R)$ & $0.125 x-12.5(0.80)$ & $-0.032 x+30.2(0.34)$ & $-0.042 x+26.3(0.36)$ & $0.041 x+16.4(0.38)$ & $0.0112 x+23.1(0.14)$ & $-0.019 x+37.6(0.05)$ & $0.025 x+26.99(0.11)$ & $-0.0325 x+36.0(0.08)$ \\
\hline Nickel $(R)$ & $0.037 x-7.61(0.90)$ & $0.022 x+1.29(0.35)$ & $-0.012 x+5.46(0.42)$ & $-0.0095 x+5.83(0.30)$ & $0.0048 x+2.36(0.25)$ & $0.0125 x+7.5(0.07)$ & $-0.005 x+6.44(0.13)$ & $-0.02 x+8.65(0.08)$ \\
\hline Lead $(R)$ & $0.029 x-4.18(0.90)$ & $0.0085 x+4.08(0.36)$ & $-0.0047 x+4.98(0.53)$ & $-0.0097 x+6.73(0.41)$ & $-0.0015 x+5.47(0.15)$ & $-0.0145 x+10.3(0.06)$ & $-0.0053 x+7.99(0.16)$ & $-0.0085 x+9.2(0.09)$ \\
\hline
\end{tabular}

\begin{tabular}{|c|c|c|c|c|c|c|c|c|c|}
\hline Mole ratio & Genders & RNACS & RACS & RCS & RAD & PNACS & PACS & PCS & PAD \\
\hline \multirow[t]{2}{*}{$\mathrm{Zn} / \mathrm{Cd}$} & Male & 722 & 130 & 268 & 219 & 178 & 48.5 & 109 & 79.9 \\
\hline & Female & 863 & 117 & 286 & 221 & 187 & 50.0 & 112 & 73.6 \\
\hline \multirow[t]{2}{*}{$\mathrm{Zn} / \mathrm{Cu}$} & Male & 22.3 & 9.81 & 14.8 & 12.8 & 11.4 & 3.16 & 5.69 & 3.96 \\
\hline & Female & 22.4 & 8.67 & 12.8 & 11.6 & 11.4 & 2.98 & 5.56 & 3.84 \\
\hline \multirow[t]{2}{*}{$\mathrm{Zn} / \mathrm{Fe}$} & Male & 12.5 & 6.17 & 10.0 & 6.85 & 7.92 & 2.44 & 5.00 & 3.35 \\
\hline & Female & 11.3 & 5.41 & 8.05 & 6.55 & 7.09 & 2.37 & 4.25 & 3.06 \\
\hline \multirow[t]{2}{*}{$\mathrm{Zn} / \mathrm{Ni}$} & Male & 135.6 & 33.1 & 61.1 & 39.6 & 50.4 & 11.7 & 23.7 & 17.7 \\
\hline & Female & 141.8 & 29.7 & 54.6 & 40.5 & 55.7 & 10.1 & 24.6 & 16.4 \\
\hline \multirow[t]{2}{*}{$\mathrm{Zn} / \mathrm{Pb}$} & Male & 259.0 & 101.2 & 151.4 & 124.9 & 135.2 & 38.3 & 70.5 & 48.6 \\
\hline & Female & 255.0 & 92.8 & 160.3 & 118.9 & 129.5 & 35.5 & 68.0 & 44.8 \\
\hline
\end{tabular}

It can also lead to high blood pressure, heart failure and an increased calorie intake. Excessive drinking and binge drinking can lead to stroke. Other serious problems include fetal alcohol syndrome, cardiomyopathy and sudden cardiac death. Cigarette smoking is a risk factor that alters low-density lipoprotein (LDL) [36], reducing the endotheliumdependent relaxation induced by acetylcholine, in a manner similar to oxidised LDL, without altering nonendothelium-dependent relaxation. Both active and passive smoking [37] are associated with the development of several clinical disorders. Smoking was the most important risk factor, considering that $48 \%$ of all the patients were smokers (Table 3). Some evidence indicated that the influence of smoking is independent but also synergistic with other risk factors such as HT, a high blood concentration of cholesterol and other physiological disorders. Cigarette smokers and people living in contaminated areas have a higher level of $\mathrm{Cd}$ in their blood and urine, with smokers having $\mathrm{Cd}$ levels more than twice as that of nonsmokers [38]. Toxic elements $(\mathrm{Cd}, \mathrm{Pb}$ and $\mathrm{Ni}$ ) may deplete glutathione and protein-bound sulfhydryl groups, resulting in the production of reactive oxygen species, such as superoxide anion, hydrogen peroxide and hydroxyl radical [39].

Tobacco leaves naturally accumulate and concentrate relatively high levels of $\mathrm{Cd}, \mathrm{Ni}, \mathrm{Pb}, \mathrm{Fe}$, $\mathrm{Cu}$, and therefore smoking of tobacco is an important source of these metals exposure for smokers [40]. The total amount of carcinogens in cigarette smoke ranges from 1 to $31.1 \mathrm{~g}$ per cigarette [40]. The country of origin and type of the product play major roles in determining 
the chemical composition of cigarette tobacco [19]. It was investigated that one pack of cigarettes deposits 2-4 $\mathrm{Rg} \mathrm{Cd}$ and 1-2 $\mathrm{Rg} \mathrm{Pb}$ and $\mathrm{Ni}$ into the lungs of a smoker, whereas some of the smoke passes into the air to be inhaled by smokers and nonsmokers alike [41]. It was also consistent with another study that smokers generally exhibit significantly higher $\mathrm{Cd}, \mathrm{Ni}$, $\mathrm{Pb}, \mathrm{Fe}$, and $\mathrm{Cu}$ body burdens than nonsmokers, while smoking with alcohol consumption enhance the $\mathrm{Cd}, \mathrm{Ni}, \mathrm{Pb}, \mathrm{Fe}$, and $\mathrm{Cu}$ absorption and accumulation in all the tissues [33]. The results suggested that although these toxic elements $(\mathrm{Cd}, \mathrm{Ni}$, and $\mathrm{Pb})$ pose a hazard to essential trace metal homeostasis of various organs, co-exposure can pose a major threat, while consumption of ethanol may absorb much more $\mathrm{Cd}$ and $\mathrm{Pb}$ than their unexposed counterparts [42].

In the past few years, increasing consideration has been given to interactions occurring in the organism between toxic metals and bioelements essential for life. These interactions are complex and involve biometals such as $\mathrm{Zn}, \mathrm{Cu}$, Fe, selenium (Se), calcium (Ca), and TEs, including $\mathrm{Cd}$ [43]. The basis of Cd toxicity is its negative influence on enzymatic systems of cells, resulting from substitution of other essential metal ions (mainly $\mathrm{Zn}, \mathrm{Cu}$, and $\mathrm{Ca}$ ) in metalloenzymes and its very strong affmity to biological structures containing - $\mathrm{SH}$ groups, such as proteins, enzymes and nucleic acids [44]. The relevance of $\mathrm{Cd}, \mathrm{Pb}, \mathrm{Ni}, \mathrm{Cu}$, and $\mathrm{Fe}-$ $\mathrm{Zn}$ interactions should be considered in the light of the general population exposure to TEs [45] and common deficiency of $\mathrm{Zn}$ in the world, mainly due to nutritional factors [46].

The concentration of zinc was found to be lower in the scalp hair samples of smokers and alcohol drinker-hypertensive patients as compare to referents of both genders (Table 6). Zinc plays an important role in normal metabolism and assists more than 200 enzymatic reactions [47]. Another biological function of $\mathrm{Zn}$ is the maintenance of the integrity of proteins, required for the stability of membrane structures [47]. Our results are consistent with other investigations, which showed that the concentration of $\mathrm{Zn}$ in blood, hair and fingernail was significantly lower in the aged patients with HT and cardiovascular diseases than in the aged healthy controls [48]. The low Zn levels may correlate with the intake of antihypertensive medication and also with reduced essential intake of macro and micro-nutrients [49]. An epidemiological study reported that low concentrations of $\mathrm{Zn}$ in serum and high concentrations of $\mathrm{Zn}$ in urine were found in patients of cardiovascular diseases, possibly because of diuretic medicines [50]. Our results indicated a high level of all TEs in hypertensive patients, with smokers and alcohol drinkers being more prone to accumulate these metals than were referents. The Cd oxides generated during the burning of cigarettes are highly bioavailable, $-10 \%$ of the inhaled $\mathrm{Cd}$ is deposited in lung tissues and $-40 \%$ is absorbed into the systemic blood circulation of smokers [51]. It was reported in a study that Thai men, who smoked an average of nine cigarettes per day for 9 years, had an approximately twofold greater body $\mathrm{Cd}$ load than did nonsmoking men of the same age [52]. In another study on men older than 50 years of age in northern Taiwan, smokers were 2.5 times more likely to excrete higher urinary Cd levels than were nonsmokers [53]. The uptake of $\mathrm{Cd}$ following environmental or occupational exposure results in a gradual accumulation in the liver and kidney, eventually resulting in kidney dysfunction and HT; its half-life in the body is not known exactly, but it may be as long as 30 years [54]. The antagonistic effect of 
$\mathrm{Cd}$ and $\mathrm{Zn}$ was investigated for the fact that the accumulation of $\mathrm{Cd}$ in the human body may replace $\mathrm{Zn}$ in the arteries, which contributes to arteries becoming brittle and inflexible. Once the arteries become inflamed and brittle, the body may coat them with $\mathrm{Ca}$ and fatty plaques to prevent their rupture [55].

This plaque unfortunately reduces the interior diameter of the arteries, resulting in more pressure being required to force the blood through the smaller diameter arteries, which in turn raises blood pressure [55]. The concentrations of $\mathrm{Cu}$ and $\mathrm{Fe}$ were higher in the scalp hair samples of smokers and alcohol drinker-hypertensive patients as compare to referents of both genders (Table 6). A portion of iron from tobacco leaf and cigarette paper is present in mainstream smoke is well established. The Fe content of tobacco has been reported to be 420 $\mathrm{Rg} / \mathrm{g}$ in 440-1,150 1.tg/g of cigarette [56]. Approximately $0.1 \%$ of the cigarette Fe is present in mainstream smoke. Thus, a one pack/day smoker can inhale over 1 pg of Fe per day [57]. Alveolar macrophages of smokers have up to six times as much $\mathrm{Fe}$ as in macrophages of nonsmokers [58]. Although about $75 \%$ of the intracellular metal is incorporated in insoluble hemosiderin, the remainder is found in ferritin and can be released by poly hydroxybenzenes in tobacco smoke [59]. Among the $>4,000$ compounds in tobacco, smoke are numerous mutagens and carcinogens [60]. The iron component, however, not only is mutagenic and carcinogenic but also uniquely possesses several additional toxic activities. A salient role of Fe is that of stimulating microbial and neoplasmic cell growth. [61]. Another critical attribute of $\mathrm{Fe}$ is its catalytic production of dangerous amounts of hydroxyl(free)radicals. In aminoglycoside antibiotic ototoxicity, the 1:1 drug-iron complex is required for radical generation [62].

Neoplasmic cell initiation, osteoblast suppression, and vascular cell toxicity likewise are attributed to iron-catalyzed hydroxyl radical formation [62]. In the association of smoking with enhanced respiratory tract infection and neoplasms, the role of inhaled Fe is more prominent than that of ingested or injected Fe. On the other hand, ingested and injected routes of Fe entry can be more accountable than inhaled Fe for the development of nonrespiratory tract disorders. Nevertheless, patients at elevated risk for diseases of Fe loading by either ingestion (e.g., hemochromatosis and African siderosis) or by erythrocyte injection (thalassemia and myelodysplasia) should be cautioned about inhaling materials laden with $\mathrm{Fe}$ such as tobacco smoke. The dietary heme Fe intake was positively and dietary Zn intake was inversely associated with the risk of cardiovascular disease (CVD) mortality among women who consumed $>10 \mathrm{~g}$ alcohol/day. Because oxidative stress is implicated as a common mechanism in the pathogenesis of various diseases, including cancer, diabetes, and CVD [63], these similar patterns with different outcomes are not surprising but rather support our hypothesis. The effect of nonheme Fe may depend on other beneficial or detrimental constituents also in the main food sources of non heme Fe: vegetables, grains, or ironfortified commercial foods such as cold breakfast cereal. Sullivan [64] proposed that Fe depletion attributable to menstruation could explain the low risk of CVD in women. Experimental and animal studies also support a potentially adverse effect of Fe overload on atherosclerosis [65, 66]. Epidemiologic studies have, nevertheless, reported conflicting results concerning Fe and CVD [67]. Although free Fe is a strong oxidant and catalyzes LDL 
oxidation in vitro, in vivo $\mathrm{Fe}$ is bound to proteins, such as ferritin or transferrin, which effectively prevents tissue damage from Fe-free radicals [68]. However, a trigger such as alcohol consumption can affect human Fe homeostasis, which leads to nontransferrin-bound Fe [69]. Any effect of Fe intake on CVD mortality would be expected among drinkers, as we observed. At the same time, our observed the association of alcohol with CVD mortality is consistent with the literature [70].

Two factors, which substantially contribute to the daily intake of $\mathrm{Cu}$, are multivitamin supplements and cigarette smoking. Cigarette smoking only adds to $\mathrm{Cu}$ and $\mathrm{Cd}$ poisoning. Public Health Service [71] found a cigarette to contain $0.19 \mathrm{ug}$ of $\mathrm{Cu}$. This accumulates in the body as smoke is inhaled as evidenced by Creason et al.'s [72] documentation of significantly higher levels of $\mathrm{Cu}$ in smokers as compared to nonsmokers. Yet another health hazard associated with smoking. Medeiros and Lui [73] have repeatedly demonstrated that rats placed on high $\mathrm{Cu}$ diets have significantly higher systolic blood pressures than those with low $\mathrm{Cu}$ intakes. Ahmed and Sackner [74] documented a similar correlation with sheep receiving infusions of $\mathrm{Cu}$ sulfate. Similarly, most hypertensive patients seen at the Princeton Brain Bio Center exhibit elevated serum $\mathrm{Cu}$ as well as depressed serum $\mathrm{Zn}$. Melanin, the natural skin pigment, seems to be a factor in the etiology of some forms of hypertension, especially in the darker skinned populations. Larsson and Tjalve [75] reported the physical properties of melanin cause it to bind heavy metal cations. This osmotically inactive pool of heavy metals was substantiated by epidemiological data, collected by Creason et al. [72], which documented significantly higher blood $\mathrm{Cu}$ and $\mathrm{Pb}$ levels in black military recruits as compared to white military recruits. Thus $\mathrm{Cu}$, through its strong correlations to hypertension and its ability to be sequestered by melanin, may well lie at the heart of the high incidence $(25 \%)$ of hypertension in the black population. Lead may also be present in high concentrations in cigarette smokers and alcohol drinker-hypertensive patients of both genders. Smokers have considerably higher levels of $\mathrm{Pb}$ in their blood than do nonsmokers [76]. Other possible health consequences of $\mathrm{Pb}$ accumulation are HT and peripheral arterial diseases [77]. Workers with chronic headache and dizziness have higher levels of $\mathrm{Cd}$ and $\mathrm{Pb}$ in the scalp hair samples, such as in those working in a fireworks factory [29]. Lead and Cd may also replace $\mathrm{Zn}$ and $\mathrm{Ca}$, contributing to the severity of HT problems. Toxic substances can accumulate in kidneys, which damage their ability to regulate the water balance in the body. This can lead to water retention, salt retention, and high blood pressure [78].

It was observed in our study that the level of $\mathrm{Ni}$ was significantly higher in smokers and alcohol drinkers hypertensive patients than in normotensive age-matched referents (Table 5). Significant Ni levels in referents smokers compared with those in smokers alcohol drinkers hypertensive patients have also been reported at $\mathrm{P}<0.003$. Besides this, the inhalation of vapors of $\mathrm{Ni}$ carbonyl obtained from burning of tobacco and from certain occupations (welding, fitting and so on) may also cause elevated Ni levels in biological samples [79]. As is the case with $\mathrm{Cd}$, tobacco plants absorb $\mathrm{Ni}$ from the soil and concentrate it in the leaves [76]. Nickel has long been known to produce nasal and lung cancers [80].

The amount of $\mathrm{Ni}$ in tobacco plant lies between 0.640 and $1.15 \mathrm{mg} / \mathrm{g}$, and varies greatly in cigarettes of different brands [80]. The possibility of trace and TEs contamination of various 
medications and its effects on the metabolism of TEs are still unknown. Experimental studies show that both metals $(\mathrm{Cd}$ and $\mathrm{Pb})$ contribute to oxidative stress by catalyzing the formation of reactive oxygen species [81], increasing lipid peroxidation [82, 83] and depleting the glutathione and protein-bound sulfhydryl groups [75]. The lipid peroxidation in patients, such as HT and cardiovascular disease, may be because of a disturbance in essential trace element metabolism and antioxidant levels [44]. In alcohol drinkers and cigarette smokers hypertensive patients, disturbances in the enzymatic mechanisms of free radicals detoxification lead to an alteration in the antioxidant system and reactive oxygen species. An attack on cell membranes also results in the formation of lipid peroxidation products [82]. In vitro and in vivo studies suggested that $\mathrm{Pb}$-induced oxidation contributes to red blood cell damage [83]. Lead and Cd may also stimulate the production of inflammatory cytokines and may induce endothelial damage by down regulating the production of nitric oxide.

\section{Conclusions}

The results of this study revealed that hypertensive patients have a different pattern of essential trace and TEs in their scalp hair samples than do controls/referents, with the prevalence being more in smoker patients and alcohol users. However, higher levels of $\mathrm{Cd}$, $\mathrm{Cu}, \mathrm{Fe}, \mathrm{Pb}$, and $\mathrm{Ni}$, as well as a lower level of $\mathrm{Zn}$, correlated well with the consequences of HT. The deficiency of the essential element, $\mathrm{Zn}$, which is replaced by trace and toxic elements $(\mathrm{Cu}, \mathrm{Fe}, \mathrm{Cd}, \mathrm{Pb}$, and $\mathrm{Ni})$, may result in abnormal physiology disorders, and, in addition to other factors, this may have a role in hypertensive and cardiovascular disease. This study provides some support for the hypothesis that dietary intake of essential elements and inhalation of trace $(\mathrm{Cu}$ and $\mathrm{Fe})$ and toxic elements $(\mathrm{Cd}, \mathrm{Pb}$, and $\mathrm{Ni})$, most probably through drinking alcohol and smoking cigarette, may increase the risk of hypertension and related disorders, which indicates that the causal link may be stronger among cigarette smokers and alcohol users. We propose that essential and toxic elemental measurements may be performed on patients reaching in the emergency department, to test whether the concentration of it may serve not only as markers of hypertension and its remedies but also as predictors of adverse outcomes.

Acknowledgments Dr. Hassan Imran Afridi is grateful to the Higher Education Commission (HEC) of Pakistan for providing the scholarships for the post doctoral research work. Dr. H.I. Afridi is also thankful to the National Center of Excellence in Analytical Chemistry, University of Sindh, Jamshoro, Pakistan for the grant of sabbatical leave.

\section{References}

1. Burt VL, Whelton P, Roccella EJ et al (1995) Prevalence of hypertension in the US adult population. Results from the Third National Health and Nutrition Examination Survey, 19881991. Hypertension 25:305-313 
2. Privitera JR, Stang A (1996) Silent clots-life's biggest killers. The Catacombs Press, Covina, pp 1-55

3. American Academy of Pediatrics October 1998 Child health month report: the risks of tobacco use: a message to parents and teens. Available at: http://www.aap.org/advocacy/chmtouse.htm (see also Milam JE (2000) Perceived invulnerability and cigarette smoking among adolescents. Addict Behav 25: 71-80)

4. Kazi TG, Jalbani N, Kazi N et al (2008) Evaluation of toxic metals in blood and urine samples of chronic renal failure patients, before and after dialysis. Ren Fail 30:737-745

5. Kazi TG, Memon AR, Afridi HI et al (2008) Determination of cadmium in whole blood and scalp hair samples of Pakistani male lung cancer patients by electro thermal atomic absorption spectrometer. Sci Total Environ 389:270-276

6. Fitzpatrick TM, Blair EA (2000) Smoking and pulmonary and cardiovascular disease: upper airway complications of smoking. Clin Chest Med 21:147-157

7. McCord JM (1998) Iron, free radicals and oxidative injury. Semin Hematol 35:5-12

8. McGowan SE, Murray JJ, Parrish MG (1986) Iron binding, internalization, and fate in human alveolar macrophages. J Lab Clin Med 108:587-595

9. Clegg MS, Ferrell F, Keen CL (1987) Hypertension-induced alterations in copper and zinc metabolism in Dahl Rats. Hypertension 9:624-628

10. World Health Organization (1974) Trace elements in cardiovascular diseases 45:1

11. Soylak M, Kidnap M (2001) Serum copper and zinc concentrations of patients with rheumatoid arthritis from Kayseri-Turkey. Fresenius Environ Bull 10:409-410

12. Soylak M, Saracoglu S, Divrildi U, Elci L (2001) Copper and zinc concentrations of serum samples of healthy people living in Tokat, Turkey. Trace Elem Electrolytes 18:47-50

13. Hennig B, Meerarani P, Toborek M, Mc-Clain C (1999) Antioxidant-like properties of zinc in activated endothelial cells. J Am Coll Nutr 18:152-158

14. Memon AR, Kazi TG, Afridi HI et al (2007) Evaluation of zinc status in whole blood and scalp hair of female cancer patients. Clin Chim Acta 379:66-70

15. Kozlowski LT, Connor RJ (2002) Cigarette filter ventilation is a defective design because of misleading taste, bigger puffs, and blocked vents. Tob Control 11:140-150

16. Wagner GJ (1993) Accumulation of cadmium in crop plants and its consequences to human health. Adv Agron 51:173-212

17. Chiba M, Masironi R (1992) Toxic and trace-elements in tobacco and tobacco-smoke. Bull WHO 70:269-275 
18. Reilly C (2002) Metal contamination of food its significance for food quality and human health. Blackwell, Oxford

19. Csalari J, Szantai K (2002) Transfer rate of cadmium, lead, zinc and iron from the tobacco-cut of the most popular Hungarian cigarette brands to the combustion products. Acta Aliment 31:279-288

20. Klaus KA, Witte MB, Andrew Let al (2001) Chronic heart failure and micronutrients. J Am Coll Cardiol 37:1765-1774

21. Gillman MW, Cook NR, Evans DA et al (1995) Relationship of alcohol intake with blood pressure in young adults. Hypertension 25:1106-1110

22. Ueshima H, Ozawa H, Baba S et al (1992) Alcohol drinking and high blood pressure: data from a 1980 national cardiovascular survey of Japan. J Clin Epidemiol 45:667-673

23. Veenstra J, Schenkel JA, van Erp-Baart AM et al (1993) Alcohol consumption in relation to food intake and smoking habits in the Dutch National Food Consumption Survey. Eur J Clin Nutr 47:482-489

24. Nawrot TS, Thijs L, Den Hond EM et al (2002) An epidemiological reappraisal of the association between blood pressure and blood lead: a metaanalysis. J Hum Hypertens 16:123131

25. Witte KKA, Nikitin NP, Parker AC et al (2005) The effect ofmicronutrient supplementation on quality-of-life and left ventricular function in elderly patients with chronic heart failure. Eur Heart J 26:2238-2244

26. Tuzen M (2002) Determination of some trace elements in whole blood and serum by GFAAS. Trace Elem Electrolytes 19(4):202-204

27. Kazi TG, Afridi HI, Kazi N et al (2008) Distribution of zinc, copper and iron in biological samples of Pakistani myocardial infarction (1st, 2nd and 3rd heart attack) patients and controls. Clin Chim Acta 389:114-119

28. Soylak M, Turkoglu 0 (1999) Trace metal accumulation caused by traffic in agricultural soil near a motorway in Kayseri-Turkey. J Trace Microprobe T 17:209-217

29. Sari A, Ttizen M, Soylak M (2007) Adsorption of Pb (II) and Cr (III) from Aqueous Solution on Celtek Clay. J Hazard Mater 144:41-46

30. Soylak M, Saraymen R, Dogan M (1995) Investigation of lead, chromium, cobalt and molybdenum concentrations in hair samples collected from diabetic patients. Fresenius Environ Bull 4:485-490

31. Afridi HI, Kazi TG, Kazi N et al (2008) Evaluation of status of toxic metals in biological samples of diabetes mellitus patients. Diabetes Res Clin Pract 80:280-288 
32. Sari H, Tiizen M, Mendil D, Hasdemir E (2006) Trace metal contents in human hair from industrial and residential areas in Tokat, Turkey. Trace Elem Electrolytes 23(1):1-4

33. Tuzen M, Soylak M (2009) Multi-element coprecipitation for separation and enrichment of heavy metal ions for their flame atomic absorption spectrometric determinations. J Hazard Mater 162:724-729

34. Citak D, Tuzen M (2010) A novel preconcentration procedure using cloud point extraction for determination of lead, cobalt and copper in water and food samples using flame atomic absorption spectrometry. Food Chem Toxicol 48(5):1399-1404

35. Afridi HI, Kazi TG, Kazi GH et al (2006) Analysis of heavy metals in scalp hair samples of hypertensive patients by conventional and microwave digestion methods. Spectrosc Lett 39:203-214

36. Kagota S, Yamaguchi Y, Shinozuka K et al (1996) Cigarette smoke-modified low density lipoprotein impairs endothelium-dependent relaxation in isolated rabbit arteries. Gen Pharmacol 27:477-481

37. Kawachi I, Colditz GA, Speizer FE et al (1997) A prospective study of passive smoking and coronary heart disease. Circulation 95:2374-2379

38. Landsberger S, Wu D (1995) The impact of heavy metals from environmental tobacco smoke on indoor air quality as determined by Compton suppression neutron activation analysis. Sci Total Environ 173:323-337

39. Goyer RA (1996) Toxic effects of metals. In: Klaassen CD (ed) Casarett and Doull's toxicology: the basic science of poisons, vol 5. McGraw-Hill, New York, pp 691-736

40. Hecht SS (2003) Tobacco carcinogens, their biomarkers and tobacco-induced cancer. Nat Rev Cancer 3:733-744

41. Kazi TG, Jalbani N, Arain MB et al (2009) Toxic metals distribution in different components of Pakistani and imported cigarettes by electrothermal atomic absorption spectrometer. J Hazard Mater 163:302-307

42. Sharma G, Sandhir R, Nath R, Gill K (1991) Effect of ethanol on cadmium uptake and metabolism of zinc and copper in rats exposed to cadmium. J Nutr 121:87-91

43. Brzoska MM, Moniuszko-Jakoniuk J, Jurczuk M, Chraniuk M (1997) The influence of cadmium on bone tissue in rats. Pol J Environ Stud 6:29-32

44. Stohs SJ, Bagchi D (1995) Oxidative mechanisms in the toxicity of metal ions. Free Radic Biol Med 18:321-336

45. Waalkes MP, Coogan TP, Barter RA (1992) Toxicological principles of metal carcinogenesis with special emphasis on cadmium. Crit Rev Toxicol 22:175-201

46. Lonnerdal B (1993) Dietary factors influencing zinc absorption. J Nutr 130:1378-1383 
47. Henning B, Meerarani P, Ramadass $\mathrm{P}$ et al (1999) Zinc nutrition and apoptosis of vascular endothelial cells: implications in atherosclerosis. Nutrition 15:744-748

48. Tang YR, Zhang SQ, Xiong Yet al (2003) Studies of five microelement contents in human serum, hair, and fingernails correlated with aged hypertension and coronary heart disease. Biol Trace Elem Res 92:97-104

49. Eltayeb MA, Van Grieken RE (1990) Iron, copper, zinc and lead in hair from Sudanese populations of different age groups. Total Environ 95:157-165

50. Wastney ME, Ahmed S, Henkin RI (1992) Changes in regulation of human zinc metabolism with age. Am J Physiol 263:R1 162—R1 168

51. Wagner KA, McDaniel R, Self D (2001) Collection and preparation of side stream cigarette smoke for trace elemental determinations by graphite furnace atomic absorption spectrometry and inductively coupled plasma mass spectrometry. JAOAC International 84:1934-1940

52. Satarug S, Vanavanitkun Y, Baker JR et al (2004) Influence of body iron store status and cigarette smoking on Cd body burden of healthy Thi man and women. Toxicol Lett 148:177185

53. Chen YC, Pu YS, Lin RS et al (2001) Blood and urine cadmium levels in relation to demographic and life style in middle aged and elderly men. Bull Environ Contam Toxicol $66: 287-294$

54. Dickel H, Kuss 0, Schmidt A, Diepgen TL (2002) Occupational relevance of positive standard patch-test results in employed persons with an initial report of an occupational disease. Int Arch Occup Environ Health 75:423-434

55. Cohen N, Golik A (2006) Zinc balance and medications commonly used in the management of heart failure. Heart Fail Rev 11:19-24

56. Mussala-Rauhammae H, Salmela SS, Lepannen A, Pyysalo H (1986) Cigarettes as a source of some trace and heavy metals and pesticides in man. Arch Environ Health 41:49-55

57. Thompson AB, Bohling T, Heires A et al (1991) Lower respiratory tract iron burden is increased in association with cigarette smoking. J Lab Clin Med 117:493-499

58. McGowan SE, Henley SA (1988) Iron and ferritin contents and distribution in human alveolar macrophages. J Lab Clin Med 111:611-617

59. Lapenna D, de Gioia S, Mezzattgi A et al (1995) Cigarette smoke, ferritin and lipid peroxidation. Am J Respir Crit Care Med 151:431-435

60. Newcomb PA, Carbone PP (1992) The health consequences of smoking. Med Clin North Am 76:305-329 
61. Drakesmith H, Prentice A (2008) Viral infection and iron metabolism. Nat Rev Microbiol 6:541-552

62. Forge A, Schacht J (2000) Aminoglycoside antibiotics. Audiol Neurootol 5:3-22

63. de Valk B, Marx JJ (1999) Iron, atherosclerosis, and ischemic heart disease. Arch Intern Med 159:1542-1548

64. Sullivan JL (1981) Iron and the sex difference in heart disease risk. Lancet 1:1293-1294

65. Steinbrecher UP, Zhang HF, Lougheed M (1990) Role of oxidatively modified LDL in atherosclerosis. Free Radic Biol Med 9:155-168

66. Halliwell B, Chirico S (1993) Lipid peroxidation: its mechanism, measurement, and significance. Am J Clin Nutr 57(suppl):7155-7245

67. Danesh J, Appleby P (1999) Coronary heart disease and iron status: metaanalyses of prospective studies. Circulation 99:852-854

68. Ponka P, Beaumont C, Richardson DR (1998) Function and regulation of transferring and ferritin. Semin Hematol 35:35-54

69. De Feo TM, Fargion S, Duca L et al (2001) Non-transferrin-bound iron in alcohol abusers. Alcohol Clin Exp Res 25:1494-1499

70. Kannel WB, Ellison RC (1996) Alcohol and coronary heart disease: the evidence for a protective effect. Clin Chim Acta 246:59-76

71. Surgeon General (1979) U.S. Department of Health, Education and Welfare, Washington

72. Creason J, Hammer D, Colucci A et al (1976) Blood trace metals in military recruits. South Med J 69:289-293

73. Lui CF, Medeiros D (1986) Excess diet copper increases systolic blood pressure in rats. Biol Trace Elem Res 9:15

74. Ahmed I, Sackner M (1985) Increased serum copper in primary pulmonary hypertension: a possible pathogenic link? Respiration 47:243-246

75. Larsson B, Tjalve H (1978) Studies on the melaninaffinity of metal ions. Acta Physiol Scand 104:479-484

76. Mannino DM, Albalak R, Grosse S, Repace J (2003) Secondhand smoke exposure and blood lead levels in US children. Epidemiology 14:719-727

77. Navas-Acien A, Selvin E, Sharrett AR et al (2004) Lead, cadmium, smoking, and increased risk of peripheral arterial disease. Circulation 109:3196-3201 
78. Staessen JA, Roels H, Fagard R (1996) Lead exposure and conventional and ambulatory blood pressure: a prospective population study, Phee Cad Investigators. JAMA 275:16041606

79. Tian L, Lawrence DA (1996) Metal-induced modulation of nitric oxide production in vitro by murine macrophages: lead, nickel and cobalt utilize different mechanisms. Toxicol Appl Pharmacol 141:540-547

80. Torjussen W, Zachariasen H, Andersen I (2003) Cigarette smoking and nickel exposure. J Environ Monit 5:198-201

81. Richard MJ, Arnoud J, Jurkovitz C et al (1991) Trace elements and lipid peroxidation abnormalities in patients with chronic renal failure. Nephron 57:10-15

82. Ding Y, Gonick HC, Vaziri ND (2000) Lead promotes hydroxyl radical generation and lipid peroxidation in cultured aortic endothelial cells. Am J Hypertens 13:552-555

83. Yiin SJ, Chem CL, Sheu JY et al (1999) Cadmium-induced renal lipid peroxidation in rats and protection by selenium. J Toxicol Environ Health A 57:403-413 